\title{
ДОСВІД ВИКЛАДАННЯ ЗАГАЛЬНОЇ ХІРУРГІЇ ЗА КРЕДИТНО- МОДУЛЬНОЮ СИСТЕМОЮ ОРГАНІЗАЦІЇ НАВЧАЛЬНОГО ПРОЦЕСУ
}

\author{
О. Ю. Іоффе, М. М. Стець, В. М. Меллін, В. М. Перепадя, Т. М. Галига \\ Наиіональний медичний університет імені О. О. Богомольия
EXPERIENCE OF TEACHING GENERAL SURGERY FOR CREDIT- MODULAR SYSTEM OF EDUCATIONAL PROCESS \\ O. Yu. Ioffe, M. M. Stets, V. M. Mellin, V. M. Perepadya, T. M. Halyha \\ National Medical University by O. O. Bohomolets
}

\begin{abstract}
У статті висвітлено досвід викладання загальної хірургії за кредитно-модульною системою організації навчального процесу.
\end{abstract}

The article highlights the experience of teaching general surgery for credit-modular system of educational process.

Вступ. Кінцева мета підписання Україною Болонської конвенції з намірами інтегруватися до загальноєвропейського освітнього простору та приєднатися до світових норм і стандартів полягає у досягненні якісно нового-вищого рівня підготовки спеціалістів, зокрема лікарів, в нашій державі. Практична реалізація Болонських засад обумовила перехід на кредитно-модульну систему навчання (КМСH), що привела до суттєвих змін змісту та структури навчальних програм і засобів їх реалізації $[1,2]$.

Досвід впровадження КМСН став предметом обговорення на численних з'їздах, конференціях та сторінках друкованих видань. В публікаціях на цю тему містяться доволі важливі спостереження, викриваються недоліки, надаються рекомендації, спрямовані на покращення процесу викладання в медичних вузах. Однак загальні характеристики Болонського процесу досить полярні: від незаперечно позитивних до вкрай негативних $[3,4]$. Водночас від кінцевих висновків і об'єктивної оцінки всього процесу навчання залежить визначення подальшого напрямку розбудови медичної освіти, а досвід окремих кафедр дозволить намітити конкретні шляхи її покращення.

Мета роботи: аналіз та пошук шляхів розв'язання проблем, пов'язаних з викладанням курсу загальної хірургії за КМСНу медичних вузах країни.

Матеріали та методи: навчальна та робоча програми, навчальні плани, методичні розробки практич-

() О. Ю. Іоффе, М. М. Стець, В. М. Меллін та ін. них занять та самостійної позааудиторної роботи студентів, матеріали лекцій, журнали успішності та відпрацювань практичних занять, звіти кафедри загальної хірургії № 2 .

Враховуючи, що основою навчального процесу $є$ його методичне забезпечення, з метою їх об'єктивної оцінки і визначення недоліків застосовано аналіз змісту та можливостей реалізації програми курсу загальної хірургії. Для характеристики основних складових навчального процесу також були використані матеріали вибіркового анонімного опитування студентів 3 курсу 1 та 4 медичних факультетів НМУ ім. О. О. Богомольця, проведеного за ініціативи співробітників кафедри під кінець вивчення 2 модуля 3 загальної хірургії. До опитування на добровільній основі було довільно залучено 202 особи з 561 студента, які в 2013-2014 роках навчалися на кафедрі загальної хірургії № 2 НМУ ім. О. О. Богомольця.

3 метою визначення впливу КМСН на успішність студентів і їх активність відвідування аудиторних занять проведено порівняння кількості боржників та середній бал оцінок за 2 роки до та після введення нової системи навчання.

Основна частина. Викладання загальної хірургії за КМСН у медичних вузах України розпочато в 2007-2008 навчальному році. Накопичений відтоді досвід дозволяс різнобічно осмислити як позитивні сторони реформи, так і те, що стає на заваді кінцевих цілей ії реалізації, вимагаючи вдосконалення навчального процесу $[2,4,5]$. 
Типова навчальна програма є основою викладання кожної дисципліни. Програма з загальної хірургії для студентів медичних вузів III-IV рівнів акредитації розроблена на принципах ECTS відповідно до низки регламентуючих документів і затверджена наказом MO3 України. Зазначена програма структурована на модулі, змістові модулі та окремі теми і в цілому містить всю необхідну інформацію для викладання за КМСН. Однак цей регламентуючий документ не позбавлений деяких недоліків. Не викликає заперечення те, що вивчення загальної хірургії базується на знаннях $з$ морфологічних дисциплін. На практиці ж вивчення питань загальної хірургії часто випереджає відповідні розділи патологічної анатомії та фізіології, особливо фармакології, що порушує міждисциплінарну інтеграцію по горизонталі.

В назвах та змісті окремих тем зустрічаються застарілі поняття. Наприклад, в темі "Вчення про кров" фігурує термін “"переливання крові”, хоча на сучасному етапі розвитку трансфузіології застосовується переливання препаратів, виготовлених з компонентів крові.

Найбільш суттєві проблеми викладання загальної хірургії пов' язані зі значним скороченням загального часу, відведеного на вивчення дисципліни за новою програмою, відповідно до європейських норм навчання. Наслідком стало вилучення з програми ряду традиційних для загальної хірургії тем та механічне перенесення всього першого змістового модуля на 2 курс до програми догляду за хворими в хірургії. Однак змістовно-тематичне перенавантаження більшості 3 залишених на курсі загальної хірургії 25 тем практичних занять достатньою мірою не зменшилося. Недоцільним і нелогічним видається вилучення 3 програми загальної хірургії таких важливих тем, як "Шок” і "Гострі гнійні захворювання серозних оболонок (перитоніт, плеврит та ін.)”, а також віднесення до іншої дисципліни: “Догляд за хворими” тем "Асептика", “Антисептика", які складають основу загальної хірургії і повинні формувати професійний світогляд майбутніх лікарів. При цьому не слід забувати, що на пропедевтичних кафедрах відбувається формування базових професійних навичок і вмінь за рахунок первинного вивчення та відпрацювання раніше невідомих матеріалів і дій. Однак на сім практичних занять розділу виробничої практики з догляду за хворими в хірургії припадає така величезна кількість різноманітного теоретичного матеріалу та практичних навичок, що реальне їх засвоєння можливе лише на найнижчому рівні - ознайомленні.

Згідно з програмою, до основних видів навчальної діяльності студентів під час опанування дисципліни
“Загальна хірургія” відносяться: лекції, практичні заняття та самостійна робота.

Тематика лекційного курсу, на який відведено 30 академічних годин, охоплює основні розділи програми. Однак на сьогодні лекції частково втратили значення основного джерела інформації. Їх головними напрямками стали презентація, постановка проблемних питань, створення активної пізнавальної мотивації до практичного опанування відповідних розділів дисципліни тощо. Враховуючи це, вважаємо доцільним замінити три лекції, присвячені конкретним питанням гнійної хірургії, однією узагальнюючою. Натомість, повернути до лекційного плану теми “Шок” та “Гнійні захворювання серозних порожнин” і, відповідно, надати можливість до їх самостійного опанування. Слід визнати, що ні застосування мультимедійного супроводу, ні демонстрація унікальних власних матеріалів та випадків із практики інтерес студентів до відвідування лекцій не підвищили. Конспекти лекцій є найменш популярним джерелом інформації. Згідно з результатами анкетування, під час підготовки до практичних занять і ПМК, поряд з іншими джерелами, ними користуються 20 \% студентів. При цьому підручники використовують $78 \%$, методичні розробки кафедри - 59 \%, матеріали Інтернету - 36 \% студентів. Цікаво, що до Інтернету, як додаткового джерела інформації, звертаються $78 \%$, а от монографії читають лише 3,4 \% студентів.

Організація практичних занять є найбільш складним і відповідальним етапом реалізації навчального процесу. Під час практичних занять з загальної хірургії найбільш гостро потребують конкретного рішення як глобальні завдання: чого і як вчити студентів, так i повсякденні питання підготовки до занять: забезпечення наглядності викладання, організації роботи біля ліжка хворого, контроль і оцінка рівня знань та ін.

Суперечність між обсягом необхідного навчального матеріалу і скороченням майже в 4 рази часу, виділеного програмою на практичні заняття, спонукає до додаткового винесення деяких тем для самостійного позааудиторного опанування. Успішній реалізації всіх етапів типових практичних занять сприяло збільшення їх тривалості до 3 академічних годин.

Важливою складовою навчального процесу, чинником, який стимулює і спрямовує пізнавальну діяльність студентів, є контроль і оцінка їх успішності. Під час поточного і підсумкового визначення рівня знань навчальна програма з загальної хірургї рекомендує надавати перевагу стандартизованим методам контролю: тестам, структурованим письмовим задачам, контролю практичних навичок в умовах, 
наближених до реальних та ін. Власне тестовий контроль став майже головною прикметою Болонської системи і головним об' єктом для ії̈ критики. Не можна залишати поза увагою такі недоліки лише тестової перевірки знань, як обмеження спілкування з викладачем, відсутність стимуляції розвитку дидактичних навичок, повноцінного предметно-логічного мислення та ін. Надмірне захоплення тестуванням обмежує необхідну для повноцінного процесу пізнання єдність зорових, локомоторних, сенсорних і віртуальних дій, веде до примітивізації та роботизації особистості. Практика застосування лише одних тестів під час поточного та підсумкового контролю показала їх недостатню об’ єктивність тому, що:

- рамки однієї вузької теми вже самі по собі містять підказку правильної відповіді;

- клінічні питання не завжди мають однозначне вирішення;

- студенти достатньо озброєні сучасними шпаргалками - електронними засобами копіювання і передачі інформації.

Останнє вимагає постійних змін формату засобів тестування, особливо в письмовому варіанті, на що витрачається значна кількість часу співробітників кафедр, матеріалів та коштів. Проте використання тестових питань і ситуаційних задач на початку заняття для оцінки вихідного рівня знань, отриманих під час самостійної передаудиторної підготовки, дає можливість при відносній економії часу одразу охопити весь обсяг заданого матеріалу, розвиває уміння інтерпретувати конкретні питання і приймати єдині рішення. 3 метою додаткової економії часу до перевірки результатів тестування доцільно залучати лаборантів та найбільш успішних студентів.

Ніщо не може замінити вплив усного спілкування викладача зі студентом на розвиток в останніх дидактичних навичок, спроможності формувати і висловлювати свої думки, набуття професійних якостей, необхідних для спілкування майбутнього лікаря з хворим. Оскільки опитування займає багато часу, його доцільно проводити під час основного етапу заняття, як коментар до виконання практичних навичок тощо. На наш погляд, лише комплексне застосування всіх зазначених способів дозволяє найбільш об'єктивно оцінити рівень знань студентів. Однак серед учасників анкетування найефективнішим способом контролю 50 \% вважають усне опитування, 34 \% - демонстрацію виконання практичних навичок, $18 \%$-тестовий контроль, а їх комплексне застосування - $28 \%$.

Оцінка з загальної хірургії виставляється кожному студенту під час кожного практичного заняття і вклю- чає результати тестового контролю, відповіді на усні структуровані питання та демонстрацію практичної діяльності. Оцінюючи останню, враховуємо зовнішній вигляд, виробничу активність студента, дотримання ним принципів деонтології та санітарно-охоронного режиму в хірургічному стаціонарі.

Основний етап практичних занять із загальної хірургіï, який займає 70 хв (65 \%) навчального часу, відведено на професійний тренінг, оволодіння та вдосконалення практичних навичок і вмінь згідно з визначеною програмою темою. Під час нього студенти також повинні навчитися загальних правил роботи в лікувальному закладі, зокрема підрозділах хірургічної клініки, навичок спілкування з пацієнтами, застосовувати на практиці теоретичні знання, залучатися до лікувального процесу. Відповідно до психолого-педагогічної структури засвоєння знання ця ланка пізнавальних дій повинна забезпечити рівні закріплення та застосування нових знань на практиці. Однак студенти, знання яких оцінюється на трійку, ледь досягають рівня “засвоєння”. Кращим засобом опанування професійних навичок вважається безпосередня індивідуальна робота студентів з пацієнтами - "навчання на хворих", яка відбувається під контролем викладача. Проте на сьогодні така організація практичного заняття в клінічних умовах пов’ язана з рядом труднощів. 3 одного боку, це викликано зменшенням кількості хворих у хірургічних відділеннях за рахунок скорочення ліжкових фондів, матеріальних нестатків частини населення, з іншого - значним збільшенням кількості студентів, що одночасного перебувають в клініці, особливо у весняному семестрі внаслідок відміни традиційних літніх виробничих практик на 2 та 3 курсах і їх проведення у вигляді практичних занять за загальним розкладом. Все це призводить до значного перенавантаження клініки i хворих студентами та порушення санітарногігієнічних норм. Зміни в Україні економічних засад, правових і етичних норм з усвідомленням необхідності беззаперечного дотримання прав людини і пацієнта стали причиною того, що більшість хворих негативно ставиться до виконання ролі об'єкта спостереження, обстеження і тим більш тренувальних маніпуляцій. Слід визнати, що хворі після хірургічних втручань, травм, страждаючі від гострих запальних захворювань та ін. обтяжені больовим синдромом і мають об'єктивні підстави відмовитися від таких процедур, особливо їх виконання недостатньо компетентними особами.

На наш погляд, розв' язання перелічених проблем повинно здійснюватися в декількох напрямках. Ра- 
дикальним є створення власних клінік вищих медичних навчальних закладів. Однак вирішення цього питання є компетенцією державних установ вищого рівня і тому зараз маловірогідне. Зменшення кількості студентів в академічній групі під час занять на клінічних кафедрах від теперішніх 10-12 до 5-6 осіб, що, до речі, передбачено Болонською угодою, дозволить зменшити навантаження на хворих, напруження праці викладачів, розширить можливості для самостійної роботи студентів, однак вимагає додаткових фінансових вкладень. Найбільш реальним вбачається оптимізація розкладу у вигляді максимально можливого скорочення числа академічних груп, що одночасно приходять на заняття в клініку. Досвід нашої кафедри свідчить про те, що покращення умов проведення педагогічного процесу на клінічних кафедрах залежить від досягнення іiі співробітниками і в першу чергу завідувачем високого рівня фахової підготовки, провідних позицій у лікувально-діагностичному процесі, застосування в роботі новітніх технологій.

Успішність реалізації кінцевих цілей практичних занять у клініці значною мірою також залежить від ступеня попередньої технічної і морально-психологічної підготовки студентів. Насамперед це стосується початкового етапу клінічного навчання. Розпочинаючи опанування пропедевтичних дисциплін, більшість студентів, навіть тих, хто отримав середню медичну освіту, не мають достатнього досвіду спілкування 3 хворими, не володіють основами практичного застосування медичної етики і деонтології, правил роботи в умовах санітарно-протиепідемічного режиму. Зважаючи на це, час основного етапу практичних занять 3 загальної хірургії доцільно розподіляти на 2 частини. Першу проводимо в навчальному класі в режимі імітаційного тренінгу. Такі передбачені програмою практичні навички, як техніка накладання бинтових пов'язок, транспортних шин, тимчасова зупинка кровотеч, штучне дихання, закритий масаж серця та ін., студенти опрацьовують один на одному та на муляжах. Реалізація інших ведеться на фантомах, за допомогою комп'ютерних програм, таблиць, слайдів, відеороликів із зображенням різних видів пошкоджень, гнійних захворювань, наркозної та дихальної апаратури, операційного інструментарію. Викладачі кафедри за власною ініціативою виготовили тренувальні пристрої для виконання ін'єкцій, венесекції, трахеостомії. Багато років на кафедрі існує кабінет з доклінічного оволодіння практичними навичками. Однак сьогодні його забезпечення навчально-тренувальним приладдям не відповідає сучасним вимогам. Ми поділяємо думку інших авторів, що якісно новий рівень попереднього здобуття і вдосконалення практичних навичок та вмінь може бути досягнутий лише завдяки застосуванню нових мультимедійних технологій, створенню сучасних комп'ютерних анімаційних програм, досконалих навчальних моделей, тренувальних фантомів та ін.

Друга половина основного етапу практичного заняття відбувається безпосередньо в умовах хірургічного відділення (палатах, маніпуляційній, перев'язочній, операційній). Під час нього студенти набувають досвіду роботи в підрозділах лікувального закладу, вчаться спілкуватися з пацієнтом, проводити обстеження хворого, виконувати різні процедури, застосовувати на практиці теоретичні знання, залучатися до лікувального процесу. Нові технології вдосконалення викладання хірургії відкривають можливість спостереження та участі студентів у сучасних ендоскопічних, УЗ-дослідженнях, лапароскопічних операціях з довершеною візуалізацією анатомічної картини, патологічних змін та методів їх лікування. Слід підкреслити, що під час практичного заняття як при попередньому оволодінні тем, так і в процесі вдосконалення практичних дій студенти працюють під постійним контролем викладача.

Всупереч думці про неповну соціальну зрілість та професійну невизначеність значної частини студентів 3 курсу, аналіз анонімного опитування показав, що головним чинником мотивації навчання для $72 \% 3$ них є бажання досконало оволодіти майбутньою спеціальністю. За даними анкетування, одну з дисциплін хірургічного профілю в майбутньому бажають обрати $31 \%$ студентів, але лише незначна частина третьокурсників (5\%) свідомо прагне присвятити себе хірургії і вже почали реалізувати свої наміри, беручи участь в ургентних чергуваннях та роботі наукового студентського гуртка. Мають намір стати фахівцем однієї з дисциплін терапевтичного профілю $-17 \%$, іншої медичної спеціальності - 35 \%, не визначились - 15 \%, не бажають займатися медициною - 1,9\% учасників анкетування. Однак $89 \%$ опитаних вважають, що знання та навички, отримані під час вивчення загальної хірургії, знадобляться в подальшій професійній діяльності.

Від самого початку викладання загальної хірургії за КМСН оцінка рівня знань студентів під час ПМК на нашій кафедрі проводилась комплексно: на підставі письмового тестування, усного опитування, демонстрації виконання практичних навичок. Наш досвід дозволяє стверджувати, що такий спосіб оцінювання є найбільш об' єктивним. Брак часу при цьому ми компенсуємо за рахунок залучення до проведення 
ПМК заздалегідь призначеного відповідним розкладом професора або доцента кафедри, керівника групи та лаборанта, що перевіряє тестові завдання. Участь у проведенні ПМК викладачів вищого рангу підвищує значимість останнього в очах студентів, обумовлює коректність оцінювання та відповідальність майбутніх лікарів за підготовку до нього.

Безумовно, покращило б рівень підготовки студентів, сприяло б систематизації та довгостроковому запам'ятовуванню вивченого матеріалу виділення на підготовку до ПМК додаткового часу. Загальна кількість навчальних тижнів протягом року дозволяє залучити для цього аудиторне заняття та час перед ним на тижні, що передує ПМК. Цей захід можна визначити як передмодульну консультацію, на кожну з яких запланована 1 год аудиторного часу та 9 годин позааудиторної роботи.

Заслуговує на увагу аналіз відвідування студентами аудиторних занять, яке є невід'ємною умовою отримання медичної освіти. По нашій кафедрі, у період після запровадження КМСН кількість осіб, які мали пропуски лекцій і практичних занять під час вивчення курсу загальної хірургії, в середньому склала 18,5 \% (від 17 до 25 \% контингенту з 560-628 студентів 1-го та 4 медичного факультетів, що відвідують кафедру протягом року). В останні 2 роки викладання загальної хірургії за традиційною системою кількість “боржників" відповідно дорівнювала 19\% i $16,5 \%$. Таким чином, ми не можемо підтримати думку про те, що КМСН покращила відвідування занять [6]. Проте аналіз анкет дає підстави вважати, що ті $9 \%$ студентів, які не визначились з мотивами навчання, ті $7 \%$, які не бажають і уникають роботи 3 хворими, ті $2 \%$, які не пов'язують свою майбутню професією з медициною, і складають контингент, представники якого систематично без поважних причин пропускають заняття та демонструють низьку успішність.

На тему пропущеної лекції студенти обов'язково пишуть реферат i, крім того, під час ПМК отримують додаткове питання з відповідної теми, що також $\epsilon$ спонукальним стимулом регулярного відвідування лекції. Відпрацювання пропущених практичнихзанять здійснюється в обов'язковому порядку в позанавчальний час 6 разів на тиждень, за звичайною схемою “година за годину”. Під час відпрацювань студенти отримують консультації чергового викладача. Проблему складає те, що КМСН не регламентує термін та послідовність відпрацювання, і більшість боржників, до якої відносяться особи з низьким рівнем успішності та мотивації до навчання, відкладають їх на кінець навчального року. В цей період на відпрацювання одночасно з'являється до 20 і більше студентів, що значно погіршує організацію їх проведення, негативно впливає на засвоєння матеріалу, порушує логічно-послідовний принцип навчального процесу. Недопустимим вважаємо відпрацювання у випадках, коли студентом пропущена більша частина аудиторних занять. Вихід з даної ситуації слід шукати в посиленні адміністративних заходів, аж до виключення студента $з$ вузу або переводу на повторне навчання.

В 2005-2006 і 2006-2007 навчальних роках оцінки 3 загальної хірургії, визначені на підставі результатів перевідних іспитів, в середньому дорівнювали $3,6 \mathrm{i}$ 4,2 бала, а середні рейтингові оцінки за 2011-2012 i 2012-2013 навчальні роки, в період КМСН, відповідно 3,3 і 4,1 бала традиційної шкали. Спостерігали коливання показників успішності в різні роки, залежно від контингенту: студенти-іноземці демонстрували нижчу, а студенти 4 медичного факультету дещо вищу успішність. Однак ця різниця статистично не достовірна. Порівняння показників успішності студентів за традиційної та КМСН не $є$ коректним, бо вони отримані в різний спосіб, за різними критеріями. Можна лише говорити про тенденцію до погіршення успішності під час КМСН, що підтверджує думку М. Д. Желіби і співавторів [2]. Можливо, це пов'язано $з$ тим, що перед іспитами студенти мали час для підготовки, повторення та систематизації навчального матеріалу, що сприяло концентрації психофізіологічної активності.

Завершуючи аналіз процесу викладання загальної хірургії за КМСН, слід зазначити, що отриманий нами досвід не дозволяє дати загальну оцінку всій системі медичної освіти, але разом 3 напрацюваннями інших кафедр складає для цього об'єктивну основу. Важливе значення має обмін та поширення новацій і досвіду реалізації окремих сторін викладання за КМСН.

Реальне покращення умов викладання клінічних дисциплін може бути досягнуто завдяки:

- подальшому вдосконаленню навчальних програм, планів і розкладів;

- покращенню матеріального забезпечення кафедр фантомами, муляжами та іншим знаряддям для професійного тренінгу;

- введенню первинного - доклінічного опанування практичних навичок у навчальних класах;

- максимальному скороченню числа академічних груп, що одночасно перебувають на клінічній базі, за рахунок оптимізації розкладу;

- зменшенню кількості студентів у клінічних групах до 5-6 осіб, як це передбачає Болонська система. 


\section{ВДОСКОНАЛЕННЯ ВИЩОЇ МЕДИЧНОЇ ОСВІТИ}

Найбільш об'єктивним і одночасно розвивальним способом оцінювання рівня поточної та підсумкової підготовки студентів слід вважати комплексне застосування тестового контролю, усного опитування і демонстрації виконання практичних навичок.

Надає оптимізму те що, для 72 \% студентів 3 курсу основним мотивом навчання вже стало бажання досконало оволодіти професією лікаря: 54 \% намагаються брати активну участь у лікувальних заходах, 66 \% подобається навчатися в НМУ ім. О. О. Богомольця. Навчання на кафедрі загальної хірургії № 2 задовольняє 81 \%, не вирішили - $17 \%$, не задовольняє всього $1,5 \%$ опитаних.

Висновки: 1. Реформа вищої медичної освіти України, пов'язана з приєднанням до Болонської конвенції з метою інтеграції до загальноєвропейського простору, дає підстави сподіватися на досягнення

\section{Література}

1. Проблеми викладання дисципліни “Загальна хірургія (з оперативною хірургією та топографічною анатомією)" на сучасному етапі / М. Д. Желіба, С. Д. Хіміч, І. Н. Ошовський [та ін.] // Український журнал хірургії. - 2012. - № 1(16). -С. 126-128.

2. Передерий В. Г. Болонский процесс и будущее Украины / В. Г. Передерий//Therapia. -2010. - № 2 (44). - C. 8-10.

3. Григорьев С. П. Болонский процесс без будущего Украины / С. П. Григорьев // Новости медицины и фармации. -2011.-№ 21-22.-С. 28-29. нашою країною якісно нового рівня підготовки студентів і надання медичної допомоги.

2. Позитивними сторонами процесу викладання загальної хірургї̈ за КМСН слід вважати:

- $100 \%$ опитування студентів під час кожного заняття;

- залежність кінцевих оцінок від поточної успішності;

- рейтингова система оцінювання;

- підвищення ролі СРС.

3. Поки що немає достатніх підстав стверджувати, що КМСН:

- стимулює систематичне вивчення клінічних дисциплін;

- покращує відвідування аудиторних занять, рівень успішності.

4. Досвід викладання загальної хірургії за кредитно-модульною системою: сучасний стан, проблеми, питання / С. О. Мунтян, В. П. Кришень, С. І. Баранник [та ін.]// Вісник Української медичної стоматологічної академії. - 2009. T.9, № 1(25). - С. 362-363.

5. Викладання хірургічних хвороб із застосуванням кредитно-модульної системи / О. Б. Кутовий, С. І. Карпенко, В. В. Васильченко [та ін.] // Український журнал хірургії. 2011.-№6(15).-C. 190-192. 